\title{
Pengukuran Beban Kerja Pada Managerial Level Dan Supervisory Level Dengan Menggunakan Metode Defence Research Agency Workload Scale (DRAWS) (Studi Kasus Di Departemen UHT PT. Ultrajaya Milk Industry \& Trading Co, TBk )
}

\author{
M. Yani Syafei ${ }^{1}$, Burhan Primanintyo ${ }^{2}$, Syaefuddin $^{3}$ \\ 1,2) Fakultas Teknik, Jurusan Teknik Industri, Universitas Presiden \\ Jl. Ki Hajar Dewantara, Kota Jababeka, Cikarang Baru, Bekasi 17550 \\ Email: yanisyafei@president.ac.id, burhanp@president.ac.id \\ ${ }^{3)}$ Pegawai PT. Ultrajaya Milk Industry \& Trading Co, TBk \\ Jl. Raya Cimareme No.131, Padalarang, Kabupaten Bandung Barat \\ Email: syaefuddin@gmail.com
}

\begin{abstract}
Measurement of workload is a technique to get information about the efficiency and effectiveness of an organizational unit, or office holders through a process of research and assessment. It is conducted by using job analysis, workload analysis or other management techniques. PT. Ultrajaya Milk Industry \& Trading Co., Tbk is manufacturer of the food and beverage. The company is always trying to meet the needs of consumers by creating products with high quality and competitive price. The high stress level perceived by Managerial Level and Supervisory Level become an important reason for the Department of Ultra High Temperature (UHT) to conduct workload analysis. By measuring the employees workload, it will be known whether the workload of an employee is optimal load or overload. This situation will affect the human-performance (employee). Based on calculations by the DRAWS method is yielded the average workload score for Managerial Level of $67.37 \%$ (in the overload category), while the dominant workload variable in Central Demand (CD) is $41.60 \%$, the distribution of the mental workload is $72.60 \%$ and physical workload is $27.40 \%$. While for Supervisory Level is yielded the average workload score of $64.59 \%$ (in the overload category) ), where the dominant workload variable in Central Demand (CD) is $33.63 \%$, the distribution of the mental workload is $55.10 \%$ and physical workload is $44.90 \%$. Therefore the perceived mental workload of Supervisory Level is still relatively comparable compared to physical workload, and in contrast to the perceived Managerial Level which is dominated by mental workload.
\end{abstract}

\begin{abstract}
Abstrak
Pengukuran beban kerja merupakan suatu teknik untuk mendapatkan informasi tentang efisiensi dan efektifitas kerja suatu unit organisasi, atau pemegang jabatan melalui proses penelitian dan pengkajian yang dilakukan dengan menggunakan teknik analisis jabatan, teknik analisis beban kerja atau teknik manajemen lainnya. PT. Ultrajaya Milk Industry \& Trading Co, TBk merupakan perusahaan yang bergerak dibidang makanan \& minuman yang selalu berupaya memenuhi kebutuhan konsumen dengan membuat produk yang berkualitas tinggi dan harga yang kompetitif. Tingginya stress yang dirasakan Managerial Level dan Supervisory Level menjadi alasan penting bagi Departemen Ultra High Temperature (UHT) untuk melakukan analisis beban kerja. Melalui pengukuran beban kerja pegawai, maka akan diketahui apakah beban kerja seorang pegawai sudah optimal atau sudah berlebihan, dimana akan berpengaruh terhadap hasil kinerja pegawai yang dihasilkan. Berdasarkan hasil perhitungan dengan metode DRAWS diketahui rata-rata skor beban kerja yang diperoleh untuk Managerial Level sebesar 67,37\% (pada kategori beban kerja over-load), dimana variabel beban kerja yang dominan adalah Central Demand (CD) sebesar 41,60\%, dengan sebaran beban kerja mental sebesar $72,60 \%$ dan beban kerja fisik sebesar $27,40 \%$. Sementara untuk Supervisory Level diperoleh rata-rata skor beban kerja sebesar 64,59\% (pada kategori beban kerja over-load), dimana variabel beban kerja yang dominan adalah Central Demand (CD) sebesar 33,63\%, dengan sebaran beban kerja mental sebesar $55,10 \%$ dan beban kerja fisik sebesar 44,90\%. Dengan demikian, beban kerja mental yang dirasakan oleh Supervisory Level masih relatif sebanding dibandingkan beban kerja fisiknya, dan berbeda yang dirasakan oleh Managerial Level dimana lebih didominasi oleh beban kerja mental.

Kata kunci: beban kerja mental, beban kerja fisik, Metode DRAWS
\end{abstract}




\section{Pendahuluan}

\section{Latar Belakang Masalah}

PT. Ultrajaya Milk Industry \& Trading Co TBk adalah sebuah perusahaan susu yang berdiri sejak tahun 1950-an, dan terus berkembang dengan sangat pesat hingga mampu meraih posisi saat ini sebagai salah satu perusahaan terkemuka di Indonesia untuk produk-produk susu dan jus buah. Saat ini $90 \%$ dari keseluruhan hasil produksi perusahaan ini dipasarkan di seluruh Indonesia, sementara sisanya diekspor ke negara-negara di Asia, Eropa, Timur Tengah, Australia dan Amerika Serikat. (Ultrajaya Milk Industry \& Trading Co. TBk, 2015)

Perusahaan Ultrajaya menerapkan perencanaan produksi yang baik dan handal, sehingga para pegawai harus bekerja lebih keras dan disiplin. Hal ini disebabkan perusahaan memiliki target produksi yang harus dicapai setiap hari untuk memenuhi kapasitas produksinya dan apabila target tidak tercapai, maka perusahaan harus melakukan lembur untuk memenuhi kekurangan produksi. Departemen Ultra High Temperature (UHT) merupakan departemen terbesar yang memproduksi semua produk minuman kemasan Aseptic Brick, seperti: Tea, Milk, Juice dan Healthy. Departemen UHT pada periode tahun 2015 menargetkan jumlah produksinya sebanyak 394 Ton liter per tahun dan menargetkan kapasitas produksinya sebanyak 32,8 Ton liter setiap bulannya. (Ultrajaya Milk Industry \& Trading Co. TBk, 2015)

Dengan tuntutan produksi ini menyebabkan tingkat masalah selama proses produksi ikut bertambah / naik. Tingginya tingkat masalah yang terjadi di Departemen UHT selama proses produksi menjadi penyebab tidak tercapainya target produksi di departemen ini. Berdasarkan data yang disajikan pada tabel 1, diketahui tingkat pencapaian (achievement) produksi setiap bulannya tidak pernah tercapai, dimana rata-rata pencapaiannya sebesar $84,55 \%$.

Pengaruh dari ditentukannya target produksi yang ketat, maka menyebabkan tingkat stress yang tinggi bagi pegawai sehingga sedemikian rupa produktivitas pegawai menjadi menurun, yang ditandai dengan banyaknya pegawai yang sering tidak masuk kerja (sakit atau cuti) disebabkan faktor kesehatan pegawai yang harus bekerja diatas jam normal atau karena disebabkan faktor psikologis pegawai karena pegawai merasa stres dan depresi dengan target-target produksi yang telah ditetapkan. Dibawah ini merupakan grafik absensi pegawai untuk Managerial Level dan Supervisory Level selama periode Juli 2015 sampai dengan Desember 2015, yang disajikan pada gambar 1 dan gambar 2 .

Tabel 1. Tingkat pencapaian produksi di departemen UHT pada tahun 2015

\begin{tabular}{|l|r|r|r|}
\hline \multicolumn{1}{|c|}{ Bulan } & Perencanaan & Produksi Aktual & $\begin{array}{c}\text { Pencapaian } \\
\text { (achievement) }\end{array}$ \\
\hline Januari & $36.751 .938,00$ & $31.151 .373,00$ & $84,76 \%$ \\
\hline Februari & $29.471 .556,00$ & $25.783 .218,00$ & $87,49 \%$ \\
\hline maret & $29.119 .000,00$ & $25.655 .008,00$ & $88,10 \%$ \\
\hline April & $36.175 .000,00$ & $29.162 .606,00$ & $80,62 \%$ \\
\hline Mei & $30.157 .000,00$ & $27.822 .458,00$ & $92,26 \%$ \\
\hline Juni & $31.090 .620,00$ & $27.849 .721,00$ & $89,58 \%$ \\
\hline Juli & $41.810 .040,00$ & $34.719 .170,00$ & $83,04 \%$ \\
\hline Agustus & $28.082 .600,00$ & $22.806 .488,00$ & $81,21 \%$ \\
\hline September & $30.979 .120,00$ & $25.094 .136,00$ & $81,00 \%$ \\
\hline Oktober & $39.028 .000,00$ & $32.070 .509,00$ & $82,17 \%$ \\
\hline November & $31.448 .400,00$ & $26.015 .561,00$ & $82,72 \%$ \\
\hline Desember & $29.907 .640,00$ & $24.994 .983,00$ & $83,57 \%$ \\
\hline Total & $394.020 .914,00$ & $333.125 .231,00$ & $84,55 \%$ \\
\hline Rata-Rata & $32.835 .076,17$ & $27.760 .435,92$ & $84,55 \%$ \\
\hline
\end{tabular}

(Sumber : Ultrajaya Milk Industry \& Trading Co. TBk, 2015)

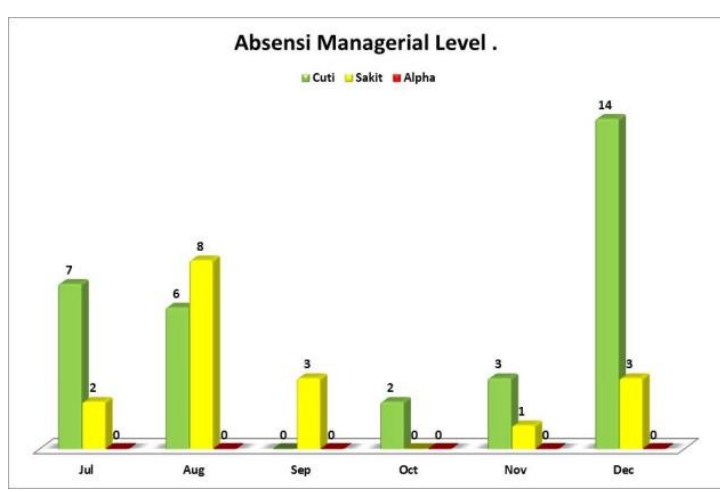

Gambar 1. Absensi managerial level

Oleh karena itu dalam upaya meningkatkan produktivitas Departemen UHT, maka sangatlah penting bagi perusahaan untuk melakukan analisis terhadap beban kerja setiap pegawai sehingga diharapkan nantinya dapat mengetahui faktor penyebab naikturunnya kinerja pegawai. Untuk mengetahui beban kerja pegawai tersebut, maka dilakukan pengukuran beban kerja. Adapun salah satu metode pengukuran beban kerja subjektif yang dapat diterapkan adalah metode DRAWS (Defence Research Agency Workload Scale). Metode ini termasuk kategori yang cukup sederhana dan mudah dalam proses perhitungannya (Salmon et al., 2004 : 348). 


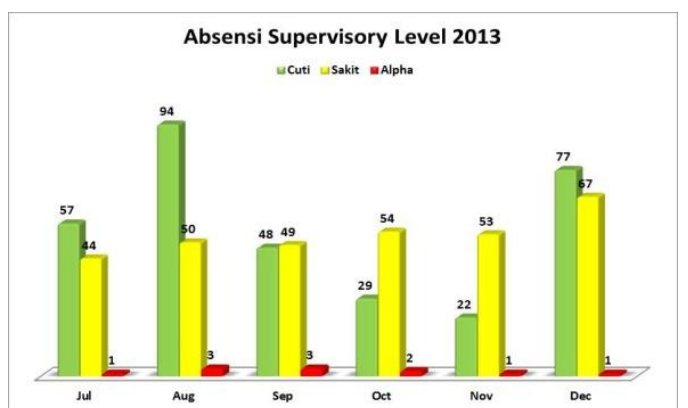

Gambar 2. Absensi supervisory level

\section{Perumusan Masalah}

Berdasarkan latar belakang masalah, maka beberapa masalah yang dirumuskan pada penelitian ini adalah sebagai berikut:

1. Seberapa besar beban kerja yang dirasakan oleh Managerial Level dan Supervisory Level melalui proses pengukuran beban kerja subjektif?

2. Variabel beban kerja DRAWS apa saja yang paling dominan dirasakan oleh Managerial Level dan Supervisory Level?

\section{Tujuan dan Manfaat Penelitian}

Berdasarkan rumusan masalah di atas, maka tujuan yang ingin dicapai dalam melakukan penelitian ini adalah sebagai berikut :

1. Untuk mengetahui nilai beban kerja yang dialami Managerial Level dan Supervisory Level di Departemen Ultra High Temperature PT. Ultrajaya Milk Industry \& Trading Co, TBk dalam melaksanakan pekerjaanya dengan menggunakan metode DRAWS.

2. Untuk mengetahui variabel beban kerja DRAWS yang paling dominan dirasakan oleh Managerial Level dan Supervisory Level.

Adapun manfaat yang diharapkan pada penelitian ini adalah sebagai berikut :

1. Memberikan rekomendasi untuk menigkatkan kinerja Managerial Level dan Supervisory Level di Departemen Ultra High Temperature PT. Ultrajaya Milk Industry \& Trading Co, TBk.

2. Sebagai pengembangan ilmu bidang ergonomi dalam kajian beban kerja.

\section{Metode Penelitian}

\section{Metode yang Digunakan}

Metode DRAWS merupakan salah satu dari metode pengukuran beban kerja subjektif, dimana metode lain yang sering digunakan adalah metode SWAT dan NASA-TLX. Metode DRAWS merupakan metode yang cukup sederhana dan sangat mudah \& cepat untuk diaplikasikan jika dibandingkan dengan metode SWAT dan NASA-TLX (Salmon et al., 2004 : 348). Metoda ini hanya melibatkan empat variabel skala pengukuran, dimana lebih mudah dan cepat dalam pengumpulan datanya dibandingkan dengan metode NASATLX yang melibatkan enam variabel skala pengukuran. Sedangkan metode SWAT adalah sangat rumit dan subjektivitas responden yang tinggi dalam pengumpulan data, dimana harus menilai pekerjaaannya dan mengurutnya melalui kartu penilaian sebanyak 27 buah.

Model pemecahan masalah yang digunakan dalam penelitian ini adalah dengan menggunakan metode DRAWS (Defence Research Agency Workload Scale). Metode ini merupakan teknik untuk mengukur mental workload secara subjektif dengan tujuan untuk mengetahui beban kerja yang didasarkan pada dimensi yang terbentuk. Metode DRAWS ini merupakan teknik penilaian beban kerja mutidimensional yang mirip dengan metode NASA-TLX (Jordan, Farmer \& Belyavin, 1995 dalam Stanton et al., 2005) yang melibatkan responden untuk dilakukan penilaian secara subjektif melalui pertanyaan dari empat variabel yang berbeda untuk memperoleh skor beban kerja secara keseluruhan (Stanton et al., 2005:335).

Empat variabel beban kerja pada pengamatan dengan metode DRAWS tersebut diantaranya yaitu: (Stanton et al., 2005:336; Salmon et al., 2004 : 346; IOE, $2005: 6$ )

1. Input Demand (merupakan beban yang terkait dengan perolehan informasi dari sumber eksternal yang diamati).

2. Central Demand (merupakan beban yang terkait dalam penafsiran informasi, mental dan proses dalam memutuskan tindakan terhadap tugas).

3. Output Demand (merupakan beban yang terkait dengan tindakan fisik atau lisan dalam suatu tugas).

4. Time Pressure (merupakan beban yang terkait dengan kendala yang berhubungan dengan tekanan waktu terhadap karyawan dalam bertindak cepat).

Keempat variabel ini merupakan rangkaian yang dirasakan oleh pekerja yang menimbulkan beban kerja mental pada pekerjaan yang mereka kerjakan, dimana keterkaitan variabelnya seperti paradigma proses manufaktur, yaitu terdapat Input (material, manusia, mesin, modal, metode), 
kemudian Process (proses manufaktur yang mentransformasi bahan baku menjadi produk jadi), dan menghasilkan Output (produk jadi yang siap dikirim ke pelangggan). Secara umum paradigma model yang digunakan dalam pemecahan masalah ini dapat dilihat pada gambar 3 .

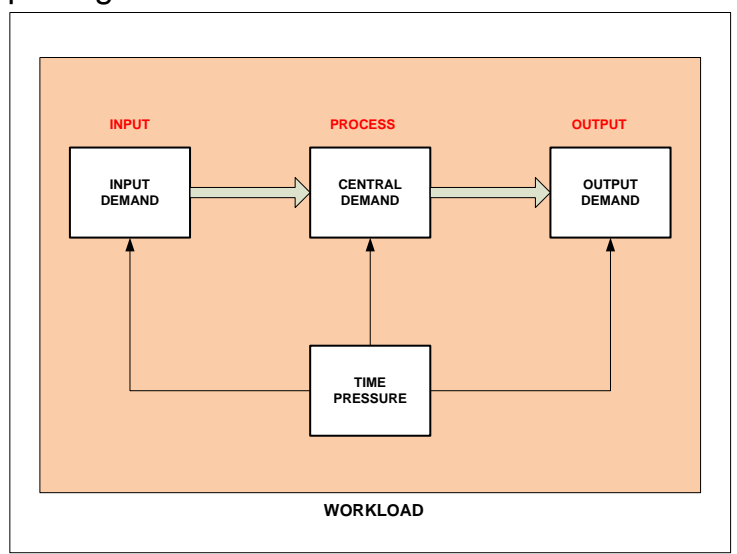

Gambar 3. Konsep beban kerja metode DRAWS

\section{Penyebaran Kuesioner}

Kuesioner disebarkan secara langsung dan bertahap terhadap 56 responden yang ada di Departemen Ultra High Temperature. Kategori responden terdiri dari 5 responden untuk Managerial Level terdiri dari 2 Manager dan 3 Assistant Manager (Shift Manager), dan 51 responden untuk Supervisory Level yang terdiri dari : 17 Supervisor dan 34 Assistant Supervisor (Foremen). Kuesioner penelitian beban kerja ini terdiri dari:

1. Deskripsi pekerjaan tehadap variabel beban kerja DRAWS.

2. Penilaian beban kerja terhadap variabel DRAWS.

3. Pembobotan terhadap tingkat kepentingan pada variabel beban kerja DRAWS.

\section{Penilaian Beban Kerja terhadap Variabel DRAWS}

Pemberian nilai beban kerja terhadap Managerial Level dan Supervisory Level untuk setiap variabel DRAWS dimulai dari nilai 0 sampai dengan 100 dalam satuan persen (\%). Tingkatan untuk penilaian beban kerja dibagi menjadi lima kategori, yaitu sebagai berikut:

1. Sangat Rendah $: 0 \% \quad \mathrm{~s} / \mathrm{d} 20 \%$

2. Rendah $: 20.1 \% \mathrm{~s} / \mathrm{d} 40 \%$

3. Sedang $: 40.1 \% \mathrm{~s} / \mathrm{d} 60 \%$

4. Tinggi $: 60.1 \% \mathrm{~s} / \mathrm{d} 80 \%$

5. Sangat Tinggi $\quad: 80.1 \% \mathrm{~s} / \mathrm{d} 100 \%$

\section{Penentuan Skor Beban Kerja}

Total skor beban kerja diperoleh dari hasil perkalian antara hasil penilaian beban kerja dengan hasil pembobotan tingkat kepentingan variabel beban kerja. Adapun Penentuan skor untuk beban kerja terhadap variabel DRAWS terdiri dari tiga kategori beban kerja dimulai dari skor $\leq 40 \%$ yaitu termasuk kedalam kategori beban kerja underload, selanjutnya $40 \%<$ skor $\leq 60 \%$ yaitu termasuk kedalam kategori beban kerja optimal load, dan yang terakhir adalah skor > 60\% yaitu termasuk kedalam kategori beban kerja overload.

\section{Hasil Pembahasan}

\section{Penilaian Beban Kerja terhadap Variabel DRAWS untuk Managerial Level}

Pemberian nilai beban kerja terhadap Managerial Level untuk setiap variabel DRAWS disajikan pada tabel 2. Sedangkan hasil rekapitulasi dari keseluruhan penilaian beban kerja terhadap variabel DRAWS disajikan pada tabel 3.

\section{Penilaian Beban Kerja terhadap Variabel DRAWS untuk Supervisory Level}

Pemberian nilai beban kerja terhadap Supervisory Level untuk setiap variabel DRAWS disajikan pada tabel 4. Sedangkan hasil rekapitulasi dari keseluruhan penilaian beban kerja terhadap variabel DRAWS untuk Supervisory Level yang terdiri dari Asisstant Supervisor dan Supervisor dapat disajikan pada tabel 5 dan tabel 6 .

\section{Pembobotan terhadap Tingkat Kepentingan pada Variabel Beban Kerja DRAWS untuk Managerial Level}

Dalam pembobotan keempat variabel beban kerja DRAWS ini dilakukan penilaian berdasarkan tingkat kepentingan beban kerja pada Managerial Level dan Supervisory Level. Dari pembobotan tersebut, kemudian dapat diperoleh nilai yang paling tinggi diantara keempat variabel beban kerja DRAWS yang dirasakan paling penting dan berpengaruh dalam melakukan pekerjaan di Departemen UHT. Adapun pembobotan terhadap tingkat kepentingan pada variabel beban kerja DRAWS untuk Managerial Level dapat disajikan pada tabel 7 . 
Tabel 2. Penilaian beban kerja variabel DRAWS untuk managerial level

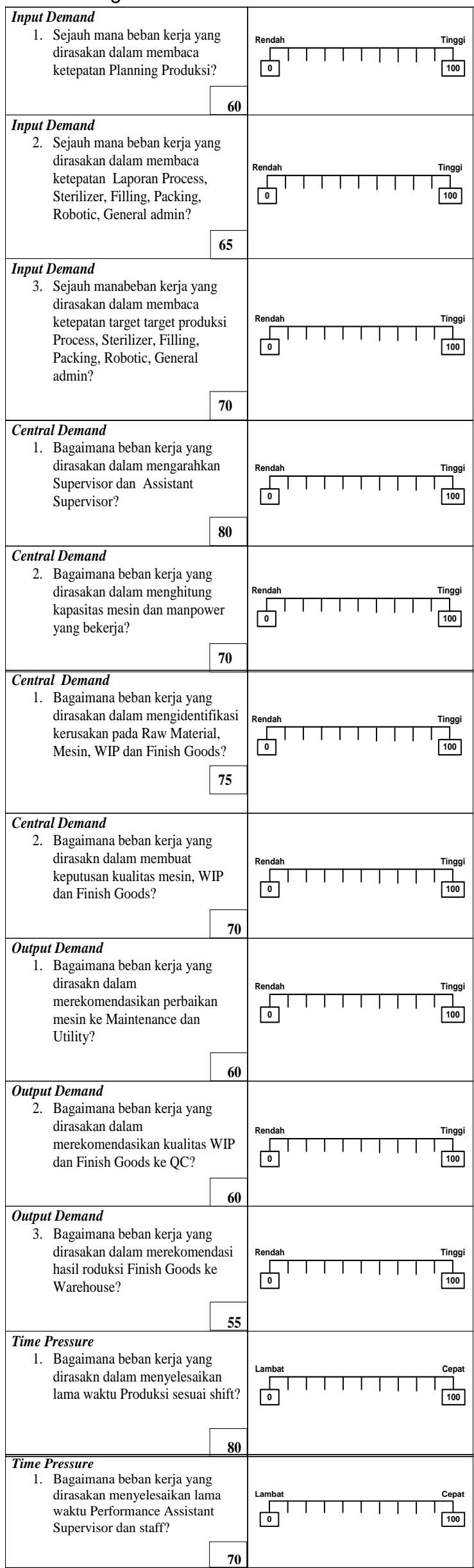

Tabel 3. Hasil rekapitulasi penilaian beban kerja DRAWS untuk managerial level

\begin{tabular}{|c|l|c|c|c|c|}
\hline \multicolumn{5}{|c|}{ Penilaian Variabel Beban Kerja DRAWS } \\
\hline \multirow{2}{*}{ No } & \multirow{2}{*}{ NAMA } & Input demand & Central Demand & Output Demand & Time Pressure \\
\cline { 3 - 6 } & & (ID) & (CD) & (OD) & (TP) \\
\hline \hline 1 & Manager 1 & 61.67 & 75.00 & 72.00 & 72.50 \\
\hline 2 & Manager 2 & 61.33 & 68.75 & 63.60 & 65.75 \\
\hline 3 & Shift Manager 1 & 65.00 & 73.75 & 60.00 & 73.33 \\
\hline 4 & Shift Manager 2 & 61.67 & 62.25 & 63.33 & 65.67 \\
\hline 5 & Shift Manager 3 & 70.00 & 65.00 & 61.67 & 61.67 \\
\hline
\end{tabular}

Tabel 4. Penilaian beban kerja variabel DRAWS untuk supervisory level

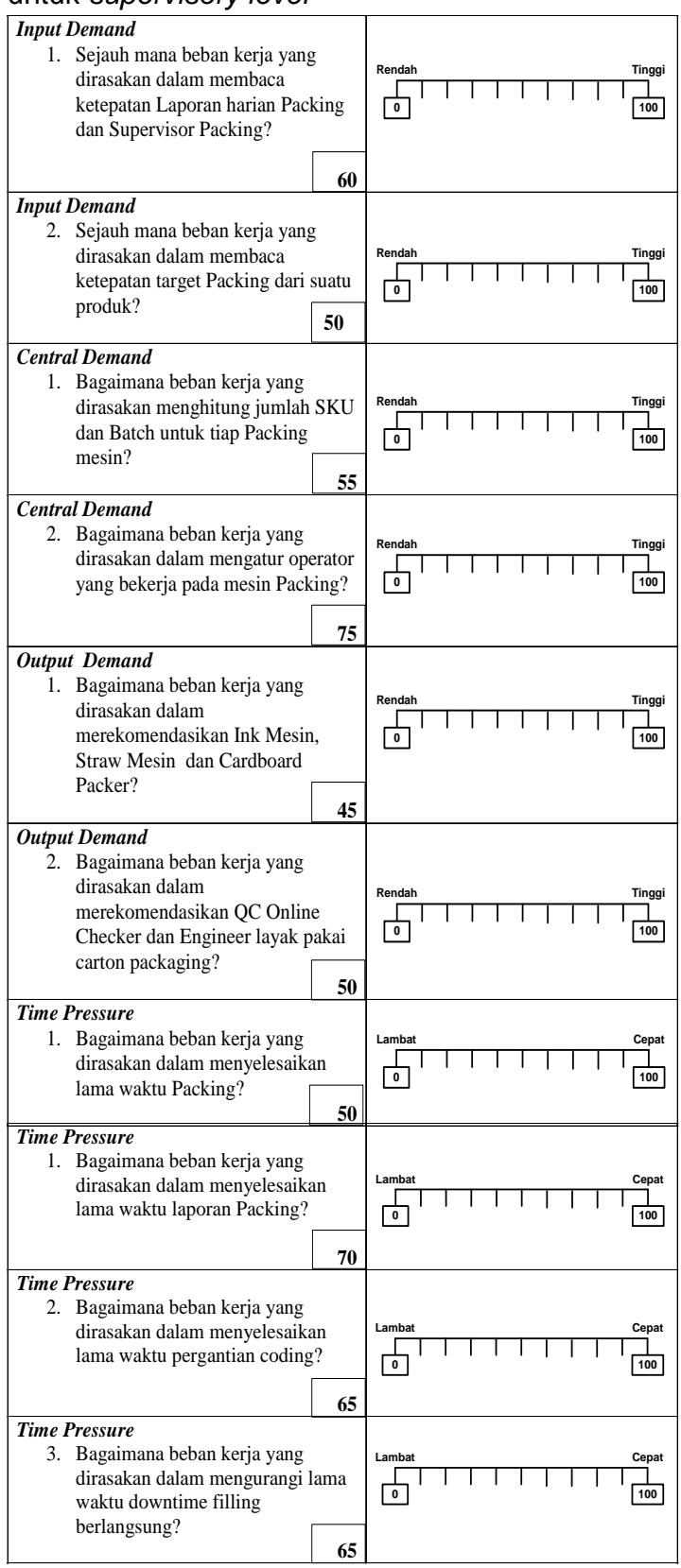


Tabel 5. Hasil rekapitulasi penilaian beban kerja DRAWS untuk assistant supervisor

\begin{tabular}{|c|c|c|c|c|c|}
\hline \multicolumn{6}{|c|}{ Penilaian Variabel Beban Kerja DRAWS } \\
\hline \multirow{2}{*}{ No } & \multirow{2}{*}{ NAMA } & Input demand & Central Demand & Output Demand & Time Pressure \\
\hline & & (ID) & $(C D)$ & $(0 D)$ & (TP) \\
\hline 1 & Deden Cahyadi & 60.00 & 62.50 & 58.33 & 60.67 \\
\hline 2 & Nana Supriatna & 47.50 & 57.50 & 60.00 & 60.00 \\
\hline 3 & Endang M & 60.00 & 62.50 & 63.33 & 60.00 \\
\hline 4 & Slamet Wijaya & 52.50 & 70.00 & 58.33 & 56.67 \\
\hline 5 & Bambang Supriyanto & 60.00 & 80.00 & 55.00 & 68.33 \\
\hline 6 & Deni S & 62.50 & 70.00 & 63.33 & 63.33 \\
\hline 7 & Wahyu & 64.50 & 70.00 & 55.00 & 66.67 \\
\hline 8 & Ari Andriyanus & 37.50 & 45.00 & 55.00 & 50.00 \\
\hline 9 & Yanyan S & 50.00 & 40.00 & 59.00 & 60.00 \\
\hline 10 & Ridho Hidayatullah & 70.00 & 55.00 & 71.50 & 75.00 \\
\hline 11 & Pegi Rustandi & 67.50 & 78.00 & 72.50 & 65.67 \\
\hline 12 & Zayus H & 67.50 & 70.00 & 65.00 & 70.00 \\
\hline 13 & Casnata & 55.00 & 60.00 & 60.00 & 58.33 \\
\hline 14 & Eko Pasharela & 75.00 & 72.50 & 80.00 & 70.00 \\
\hline 15 & Hasan & 65.00 & 71.50 & 66.50 & 71.00 \\
\hline 16 & Marno & 60.00 & 65.00 & 65.00 & 58.33 \\
\hline 17 & Iwan K & 50.00 & 61.00 & 61.50 & 63.33 \\
\hline 18 & Deden F & 72.50 & 75.00 & 72.50 & 71.67 \\
\hline 19 & Andri P & 80.00 & 82.50 & 77.50 & 71.67 \\
\hline 20 & Yanto & 57.50 & 60.00 & 65.00 & 61.25 \\
\hline 21 & Yayat Hidayat & 55.00 & 65.00 & 47.50 & 62.50 \\
\hline 22 & Mamat Rahmat & 50.00 & 55.00 & 40.00 & 44.00 \\
\hline 23 & Supriyatna & 62.00 & 72.50 & 62.50 & 63.00 \\
\hline 24 & Endang $S$ & 37.50 & 55.00 & 65.00 & 61.25 \\
\hline 25 & Yayan S & 60.00 & 67.50 & 57.50 & 61.00 \\
\hline 26 & Komar S & 40.00 & 55.00 & 57.50 & 58.75 \\
\hline 27 & Jajang Saepul H & 67.50 & 70.35 & 55.00 & 65.00 \\
\hline 28 & Dadang H & 65.00 & 70.00 & 67.50 & 68.75 \\
\hline 29 & Heri $\mathrm{H}$ & 57.00 & 57.50 & 62.50 & 53.75 \\
\hline 30 & Aep Cahyana & 70.50 & 63.50 & 62.50 & 70.50 \\
\hline 31 & Usep Rodita & 63.50 & 73.00 & 55.50 & 75.00 \\
\hline 32 & Trisnos & 35.00 & 48.33 & 38.50 & 46.50 \\
\hline 33 & Dandung $P$ & 60.00 & 69.00 & 68.00 & 71.00 \\
\hline 34 & Asep Jaenudin & 64.00 & 71.50 & 62.50 & 73.50 \\
\hline
\end{tabular}

Tabel 6. Hasil rekapitulasi penilaian beban kerja DRAWS untuk supervisor

\begin{tabular}{|c|l|c|c|c|c|}
\hline \multicolumn{5}{|c|}{ Penilaian Variabel } & Beban Kerja DRAWS \\
\hline \multirow{2}{*}{ No } & \multirow{2}{*}{ NAMA } & Input demand & Central Demand & Output Demand & Time Pressure \\
\cline { 3 - 6 } & & (D) & (CD) & (OD) & (TP) \\
\hline \hline 1 & R. Usman & 63.33 & 70.00 & 73.33 & 70.00 \\
\hline 2 & Dian Suyud & 71.67 & 67.25 & 66.33 & 73.00 \\
\hline 3 & Yayan Sugiharjo & 59.33 & 57.00 & 57.00 & 60.00 \\
\hline 4 & Dedi Ruswendi & 61.00 & 52.50 & 65.00 & 71.50 \\
\hline 5 & Kohar Fahrudin & 59.33 & 43.75 & 60.50 & 57.50 \\
\hline 6 & Budi Rahmat S.A.S & 83.33 & 83.75 & 75.00 & 87.50 \\
\hline 7 & Suhardi & 65.00 & 73.75 & 65.00 & 60.00 \\
\hline 8 & Agung WahyuS & 53.67 & 56.25 & 42.50 & 61.00 \\
\hline 9 & Fajar Fatahillah & 80.00 & 90.00 & 92.50 & 80.00 \\
\hline 10 & Yunar Wahyudi & 66.67 & 75.00 & 67.50 & 75.00 \\
\hline 11 & Dadan Mardiana & 69.67 & 67.50 & 67.50 & 67.50 \\
\hline 12 & Iwa Wardani & 70.00 & 50.00 & 80.00 & 67.50 \\
\hline 13 & Tito Gitaraharja & 66.67 & 41.25 & 70.00 & 70.00 \\
\hline 14 & Satrio & 71.67 & 51.25 & 65.00 & 72.50 \\
\hline 15 & Lies Purwaty & 66.67 & 50.00 & 75.00 & 70.00 \\
\hline 16 & Ayep Sanusi & 71.67 & 56.25 & 75.00 & 70.00 \\
\hline 17 & Syaefuddin & 76.67 & 66.00 & 82.00 & 81.67 \\
\hline
\end{tabular}

Tabel 7. Pembobotan variabel beban kerja DRAWS untuk managerial level

\begin{tabular}{|c|c|c|c|}
\hline Jabatan & Variable & Indikator & Pembobotan \\
\hline \multirow{4}{*}{ Shift Manager } & Input Demand (ID) & $\begin{array}{l}\text {-Membaca ketepatan planning produksi } \\
\text {-Membaca ketepatan Laporan Process, Sterilizer, } \\
\text { Filling, Packing, Robotic, General admin. } \\
\text {-Membaca ketepatan target target produksi Process, } \\
\text { Sterilizer, Filling, Packing, Robotic, General admin. }\end{array}$ & 5 \\
\hline & Central Demand (CD) & $\begin{array}{l}\text {-Mengarahkan Supervisor dan Assistant Supervisor. } \\
\text { - } \\
\text {-Mengidentifikasi kerusakan pada Raw Material, Mesin, } \\
\text { WIP dan Finish Goods. } \\
\text {-Membuat keputusan kualitas mesin, WIP dan Finish } \\
\text { Goods. } \\
\end{array}$ & 50 \\
\hline & Output Demand (OD) & $\begin{array}{l}\text {-Rekomendasi perbaikan mesin ke Maintenance dan } \\
\text { Utility. } \\
\text {-Rekomendasi kualitas WIP dan Finish Goods ke QC. } \\
\text {-Rekomendasi hasil produksi Finish Goods ke } \\
\text { Warehouse. } \\
\end{array}$ & 15 \\
\hline & Time Pressure (TP) & $\begin{array}{l}\text {-Penyelesaikan lama waktu Produksi sesuai shift. } \\
\text {-Penyelesaikan lama waktu Performance Assistant } \\
\text { Supervisor dan staff. } \\
\text {-Penyelesaian lama waktu Improvent Project } \\
\end{array}$ & 30 \\
\hline & & Jumlah & $100 \%$ \\
\hline
\end{tabular}

Adapun hasil rekapitulasi dari keseluruhan pembobotan terhadap tingkat kepentingan pada variabel beban kerja DRAWS untuk Managerial Level disajikan pada tabel 8.

Tabel 8. Hasil rekapitulasi pembobotan variabel beban kerja DRAWS untuk managerial level

\begin{tabular}{|c|l|c|c|c|c|c|}
\hline \multicolumn{7}{|c|}{ Pembobotan Variabel Beban Kerja DRAWS } \\
\cline { 1 - 5 } \multirow{2}{*}{ No } & \multirow{2}{*}{ NAMA } & Input demand & Central Demand & Output Demand & Time Pressure & \multirow{2}{*}{ Jumlah (\%) } \\
\cline { 3 - 6 } & & (ID) & (CD) & (OD) & (TP) & \\
\hline \hline 1 & Manager1 & 10 & 40 & 20 & 30 & 100 \\
\hline 2 & Manager2 & 15 & 40 & 15 & 30 & 100 \\
\hline 3 & Shift Manager1 & 5 & 50 & 15 & 30 & 100 \\
\hline 4 & Shift Manager2 & 7 & 37 & 25 & 31 & 100 \\
\hline 5 & Shift Manager3 & 10 & 40 & 20 & 30 & 100 \\
\hline
\end{tabular}

\section{Pembobotan terhadap Tingkat Kepentingan pada Variabel Beban Kerja DRAWS untuk Supervisory Level}

Pembobotan terhadap tingkat kepentingan pada variabel beban kerja DRAWS untuk Supervisory Level disajikan pada tabel 9.

Tabel 9. Pembobotan variabel beban kerja DRAWS untuk assistant supervisor

\begin{tabular}{|c|c|c|c|}
\hline Jabatan & Variabel & Indikator & $\begin{array}{c}\text { Pembobotan } \\
(\%)\end{array}$ \\
\hline \multirow{4}{*}{$\begin{array}{l}\text { Assistant } \\
\text { Supervisor } \\
\text { Packing }\end{array}$} & \begin{tabular}{|l} 
Input \\
Demand
\end{tabular} & $\begin{array}{l}\text {-Membaca ketepatan Laporan harian } \\
\text { Packing dan Supervisor Packing. } \\
\text {-Membaca ketepatan target produksi } \\
\text { Packing. }\end{array}$ & 5 \\
\hline & $\begin{array}{l}\text { Central } \\
\text { Demand }\end{array}$ & $\begin{array}{l}\text {-Menghitung jumlah SKU dan Batch untuk } \\
\text { tiap Packing. } \\
\text {-Mengatur mesin dan operator yang } \\
\text { bekerja. }\end{array}$ & 15 \\
\hline & $\begin{array}{l}\text { Output } \\
\text { Demand }\end{array}$ & $\begin{array}{l}\text {-Rekomendasi Ink Mesin, Straw Mesin } \\
\text { dan Cardboard Packer siap produksi. } \\
\text {-Rekomendasi QC online Checker dan } \\
\text { Engineer layak pakai carton packaging. }\end{array}$ & 30 \\
\hline & \multirow[t]{2}{*}{\begin{tabular}{|l} 
Time \\
Pressure
\end{tabular}} & $\begin{array}{l}\text {-Penyelesaikan lama waktu Packing. } \\
\text {-Penyelesaikan lama waktu laporan } \\
\text { Packing. } \\
\text {-Penyelesaian pergantian coding secara } \\
\text { benar dan tepat waktu. } \\
\text {-Mengurangi lama waktu downtime filling } \\
\text { berlangsung. } \\
\end{array}$ & 50 \\
\hline & & Jumlah & 100 \\
\hline
\end{tabular}


Sedangkan hasil rekapitulasi dari keseluruhan pembobotan terhadap tingkat kepentingan pada variabel beban kerja DRAWS untuk Supervisory Level yang terdiri dari Assistant Supervisor dan Supervisor dapat pada tabel 10 dan tabel 11 .

Tabel 10. Hasil rekapitulasi pembobotan tingkat kepentingan variabel beban kerja DRAWS untuk assistant supervisor

\begin{tabular}{|c|c|c|c|c|c|c|}
\hline \multicolumn{7}{|c|}{ Pembobotan Variabel Beban Kerja DRAWS } \\
\hline \multirow{2}{*}{ № } & \multirow{2}{*}{ NAMA } & Input demand & Central Demand & Output Demand & Time Pressure & \multirow{2}{*}{ Jumlah (\%) } \\
\hline & & (ID) & (CD) & (OD) & (TP) & \\
\hline 1 & Deden Cahyadi & 40 & 30 & 20 & 10 & 100 \\
\hline 2 & Nana Supriatna & 20 & 35 & 30 & 15 & 100 \\
\hline 3 & Endang M & 10 & 30 & 30 & 30 & 100 \\
\hline 4 & Slamet Wijaya & 20 & 43 & 27 & 10 & 100 \\
\hline 5 & Bambang Supriyanto & 10 & 40 & 30 & 20 & 100 \\
\hline 6 & Denis & 10 & 35 & 25 & 30 & 100 \\
\hline 7 & Wahyu & 10 & 30 & 35 & 25 & 100 \\
\hline 8 & Ari Andriyanus & 30 & 50 & 10 & 10 & 100 \\
\hline 9 & Yanyans & 15 & 40 & 30 & 15 & 100 \\
\hline 10 & Ridho Hidayatullah & 20 & 60 & 10 & 10 & 100 \\
\hline 11 & Pegi Rustandi & 30 & 15 & 25 & 30 & 100 \\
\hline 12 & Zayus H & 20 & 35 & 25 & 20 & 100 \\
\hline 13 & Casnata & 25 & 20 & 40 & 15 & 100 \\
\hline 14 & Eko Pasharela & 10 & 40 & 20 & 30 & 100 \\
\hline 15 & Hasan & 20 & 35 & 25 & 20 & 100 \\
\hline 16 & Marno & 20 & 35 & 30 & 15 & 100 \\
\hline 17 & Iwan K & 15 & 35 & 35 & 15 & 100 \\
\hline 18 & Deden F & 10 & 45 & 35 & 10 & 100 \\
\hline 19 & Andri P & 20 & 25 & 40 & 15 & 100 \\
\hline 20 & Yanto & 25 & 35 & 20 & 20 & 100 \\
\hline 21 & Yayat Hidayat & 30 & 25 & 20 & 25 & 100 \\
\hline 22 & Mamat Rahmat & 20 & 35 & 20 & 25 & 100 \\
\hline 23 & Supriyatna & 20 & 25 & 20 & 35 & 100 \\
\hline 24 & Endang S & 15 & 30 & 25 & 30 & 100 \\
\hline 25 & YayanS & 30 & 30 & 20 & 20 & 100 \\
\hline 26 & Komar S & 30 & 20 & 20 & 30 & 100 \\
\hline 27 & Jajang Saepul H & 20 & 35 & 30 & 15 & 100 \\
\hline 28 & Dadang H & 23 & 31 & 17 & 29 & 100 \\
\hline 29 & Heri $\mathrm{H}$ & 30 & 10 & 15 & 45 & 100 \\
\hline 30 & Aep Cahyana & 15 & 35 & 20 & 30 & 100 \\
\hline 31 & Usep Rodita & 10 & 45 & 30 & 15 & 100 \\
\hline 32 & Trisnos & 10 & 30 & 20 & 40 & 100 \\
\hline 33 & Dandung $P$ & 15 & 40 & 30 & 15 & 100 \\
\hline 34 & Asep Jaenudin & 25 & 25 & 25 & 25 & 100 \\
\hline
\end{tabular}

\section{Penentuan Skor Beban Kerja Pegawai dengan Menggunakan Metode DRAWS untuk Penilaian Managerial Level dan Supervisory Level}

Penentuan skor beban kerja pegawai diperoleh dari hasil perkalian antara hasil penilaian beban kerja dengan hasil pembobotan tingkat kepentingan variabel beban kerja DRAWS. Penentuan skor untuk beban kerja terhadap variabel DRAWS terdiri dari tiga kategori beban kerja dimulai dari skor $\leq 40 \%$ yaitu termasuk kedalam kategori beban kerja under load, selanjutnya $40 \%<$ skor $\leq$ $60 \%$ yaitu termasuk kedalam kategori beban kerja optimal load, dan yang terakhir adalah skor $>60 \%$ yaitu termasuk kedalam kategori beban kerja over load.
Tabel 11. Hasil rekapitulasi pembobotan tingkat kepentingan variabel beban kerja DRAWS untuk supervisor

\begin{tabular}{|c|l|c|c|c|c|c|}
\hline \multicolumn{7}{|c|}{ Pembobotan Variabel Beban Kerja DRAWS } \\
\hline \multirow{2}{*}{ No } & \multirow{2}{*}{ NAMA } & Input demand & Central Demand & Output Demand & Time Pressure & \multirow{2}{*}{ Jumlah (\%) } \\
\cline { 3 - 6 } & & (ID) & (CD) & (OD) & (TP) & \\
\hline \hline 1 & R. Usman & 30 & 30 & 20 & 20 & 100 \\
\hline 2 & Dian Suyud & 10 & 40 & 30 & 20 & 100 \\
\hline 3 & Yayan Sugiharjo & 23 & 27 & 26 & 24 & 100 \\
\hline 4 & Dedi Ruswendi & 13 & 42 & 28 & 17 & 100 \\
\hline 5 & Kohar Fahrudin & 30 & 20 & 25 & 25 & 100 \\
\hline 6 & Budi Rahmat S.A.S & 20 & 35 & 20 & 25 & 100 \\
\hline 7 & Suhardi & 30 & 40 & 15 & 15 & 100 \\
\hline 8 & Agung WahyuS & 37 & 30 & 16 & 17 & 100 \\
\hline 9 & Fajar Fatahillah & 10 & 60 & 15 & 15 & 100 \\
\hline 10 & Yunar Wahyudi & 20 & 35 & 20 & 25 & 100 \\
\hline 11 & Dadan Mardiana & 30 & 30 & 20 & 20 & 100 \\
\hline 12 & Iwa Wardani & 20 & 40 & 25 & 15 & 100 \\
\hline 13 & Tito Gitaraharja & 10 & 50 & 20 & 20 & 100 \\
\hline 14 & Satrio & 40 & 20 & 20 & 20 & 100 \\
\hline 15 & Lies Purwaty & 30 & 30 & 20 & 20 & 100 \\
\hline 16 & Ayep Sanusi & 35 & 35 & 10 & 20 & 100 \\
\hline 17 & Syaefuddin & 5 & 15 & 40 & 40 & 100 \\
\hline
\end{tabular}

Hasil pengolahan data dan rekapitulasi skor beban kerja pegawai dengan menggunakan metode DRAWS pada Managerial Level disajikan pada tabel 12.

Tabel 12. Hasil rekapitulasi skor beban kerja menggunakan metode DRAWS untuk managerial level

\begin{tabular}{|c|c|c|c|c|c|c|c|c|c|c|c|}
\hline \multirow{2}{*}{ No } & \multirow{2}{*}{ NAMA } & \multicolumn{4}{|c|}{ Penilaian Variabel Beeban DRAWS } & \multicolumn{4}{|c|}{ Pembobotatan Variabel Bebon DRAWS } & \multirow{2}{*}{ Shor $(y)$} & \multirow{2}{*}{$\begin{array}{c}\text { Kategoo Beban } \\
\text { Kerja }\end{array}$} \\
\hline & & (ID) & $|C D|$ & 1001 & $|\mathbb{P}|$ & (ID) & $(C D)$ & $100 \mid$ & $|\mathbb{P P}|$ & & \\
\hline & nager1 & 61.67 & 75.00 & 72.00 & 7250 & 10 & 40 & 20 & 30 & 7232 & Oover Load \\
\hline & anagerer2 & 61.33 & 68.75 & 63.60 & 65.75 & 15 & 40 & 15 & 30 & 65.96 & Oover Load \\
\hline & hititVanager1 & 65.00 & 73.75 & 60.00 & 73.33 & t & 50 & 15 & 30 & 71.12 & Overel Load \\
\hline & hititVanager2 & 61.67 & 62.25 & 6333 & 65.67 & 7 & 37 & 25 & 31 & 63.54 & Overel Load \\
\hline & hititVanager 3 & 70.00 & 65.00 & 61.67 & 61.67 & 10 & 40 & 20 & 30 & \begin{tabular}{|l|l|}
63.84 \\
\end{tabular} & Overel Load \\
\hline & Rata-Rata & 63.93 & 68.95 & 64.12 & 67.78 & 9.40 & 41.40 & 19.00 & 30.20 & 67,36 & Over Load \\
\hline
\end{tabular}

Sedangkan untuk hasil rekapitulasi Supervisory Level disajikaan pada tabel 13 dan tabel 14.

\section{Analisis Beban Kerja yang Dirasakan Managerial Level dan Supervisory Level}

Berdasarkan tabel 12 hasil rekapitulasi perhitungan beban kerja pada Managerial Level, diperoleh rata-rata skor beban kerja sebesar 67,36\%, maka kategori beban kerja untuk Managerial Level di Departemen UHT PT. Ultrajaya termasuk kedalam kategori beban kerja overload, dimana seluruh manager berada pada kategori beban kerja overload. Sedangkan berdasarkan tabel 13 dan 14 hasil rekapitulasi perhitungan beban kerja pada Supervisory Level, diperoleh ratarata skor beban kerja masing-masing sebesar $62,14 \%$ dan $67,03 \%$, maka kategori beban 
kerja untuk Supervisory Level di Departemen UHT PT. Ultrajaya termasuk kedalam kategori beban kerja over load, dimana dari 51 supervisor terdapat 15 pegawai termasuk beban kerja optimal (sekitar 29,41\%).

Tabel 13. Hasil rekapitulasi skor beban kerja dengan menggunakan metode DRAWS untuk assistant supervisor

\begin{tabular}{|c|c|c|c|c|c|c|c|}
\hline \multirow{2}{*}{ No } & \multirow{2}{*}{ NAMA } & \multicolumn{4}{|c|}{ Skoring } & \multirow{2}{*}{ Total (\%) } & \multirow{2}{*}{$\begin{array}{c}\text { Kategori } \\
\text { Beban Kerja }\end{array}$} \\
\hline & & Input Demand & Central Demand & Output Demand & Time Pressure & & \\
\hline 1 & Deden Cahyadi & $60.00 \times 40$ & $62.50 \times 30$ & $58.33 \times 20$ & $60.67 \times 10$ & 60.48 & Over Load \\
\hline 2 & Nana Supriatna & $47.50 \times 20$ & $57.50 \times 35$ & $60.00 \times 30$ & $60.00 \times 15$ & 56.63 & Optimal Load \\
\hline 3 & Endang M & $60.00 \times 10$ & $62.50 \times 30$ & $63.33 \times 30$ & $60.00 \times 30$ & 61.75 & Over Load \\
\hline 4 & Slamet Wijaya & $52.50 \times 20$ & $70.00 \times 43$ & $58.33 \times 27$ & $56.67 \times 10$ & 62.02 & Over Load \\
\hline 5 & Bambang Supriyanto & $60.00 \times 10$ & $80.00 \times 40$ & $55.00 \times 30$ & $68.33 \times 20$ & 68.17 & Over Load \\
\hline 6 & Denis & $62.50 \times 10$ & $70.00 \times 35$ & $63.33 \times 25$ & $63.33 \times 30$ & 65.58 & Over load \\
\hline 7 & Wahyu & $64.50 \times 10$ & $70.00 \times 30$ & $55.00 \times 35$ & $66.67 \times 25$ & 63.37 & Over Load \\
\hline 8 & Ari Andrivanus & $37.50 \times 30$ & $45.00 \times 50$ & $55.00 \times 10$ & $50.00 \times 10$ & 44.25 & Optimal Load \\
\hline 9 & YanyanS & $50.00 \times 15$ & $40.00 \times 40$ & $59.00 \times 30$ & $60.00 \times 15$ & 50.20 & Optimal Load \\
\hline 10 & Ridho Hidayatullah & $70.00 \times 20$ & $55.00 \times 60$ & $71.50 \times 10$ & $75.00 \times 10$ & 61.65 & Over Load \\
\hline 11 & Pegi Rustandi & $67.50 \times 30$ & $78.00 \times 15$ & $72.50 \times 25$ & $65.67 \times 30$ & 69.78 & Over Load \\
\hline 12 & Zayus H & $67.50 \times 20$ & $70.00 \times 35$ & $65.00 \times 25$ & $70.00 \times 20$ & 68.25 & Over Load \\
\hline 13 & Casnata & $55.00 \times 25$ & $60.00 \times 20$ & $60.00 \times 40$ & $58.33 \times 15$ & 58.50 & Optimal Load \\
\hline 14 & Eko Pasharela & $75.00 \times 10$ & $72.50 \times 40$ & $80.00 \times 20$ & $70.00 \times 30$ & 73.50 & Over Load \\
\hline 15 & Hasan & $65.00 \times 20$ & $71.50 \times 35$ & $66.50 \times 25$ & $71.00 \times 20$ & 68.85 & Over Load \\
\hline 16 & Marno & $60.00 \times 20$ & $65.00 \times 35$ & $65.00 \times 30$ & $58.33 \times 15$ & 63.00 & Over Load \\
\hline 17 & IWan K & $50.00 \times 15$ & $61.00 \times 35$ & $61.50 \times 35$ & $63.33 \times 15$ & 59.88 & Optimal Load \\
\hline 18 & Deden F & $72.50 \times 10$ & $75.00 \times 45$ & $72.50 \times 35$ & $71.67 \times 10$ & 73.54 & Over Load \\
\hline 19 & Andri P & $80.00 \times 20$ & $82.50 \times 25$ & $77.50 \times 40$ & $71.67 \times 15$ & 78.38 & Over Load \\
\hline 20 & Yanto & $57.50 \times 25$ & $60.00 \times 35$ & $65.00 \times 20$ & $61.25 \times 20$ & 60.63 & Over Load \\
\hline 21 & Yayat Hidayat & $55.00 \times 30$ & $65.00 \times 25$ & $47.50 \times 20$ & $62.50 \times 25$ & 57.88 & Optimal Load \\
\hline 22 & Mamat Rahmat & $50.00 \times 20$ & $55.00 \times 35$ & $40.00 \times 20$ & $44.00 \times 25$ & 48.25 & Optimal Load \\
\hline 23 & Supriyatna & $62.00 \times 20$ & $72.50 \times 25$ & $62.50 \times 20$ & $63.00 \times 35$ & 65.08 & Over Load \\
\hline 24 & Endang S & $37.50 \times 15$ & $55.00 \times 30$ & $65.00 \times 25$ & $61.25 \times 30$ & 56.75 & Optimal Load \\
\hline 25 & Yayans & $60.00 \times 30$ & $67.50 \times 30$ & $57.50 \times 20$ & $61.00 \times 20$ & 61.95 & Over Load \\
\hline 26 & KomarS & $40.00 \times 30$ & $55.00 \times 20$ & $57.50 \times 20$ & $58.75 \times 30$ & 52.13 & Optimal Load \\
\hline 27 & Jajang Saepul H & $67.50 \times 20$ & $70.35 \times 35$ & $55.00 \times 30$ & $65.00 \times 15$ & 64.37 & Over Load \\
\hline 28 & Dadang H & $65.00 \times 23$ & $70.00 \times 31$ & $67.50 \times 17$ & $68.75 \times 29$ & 68.06 & Over Load \\
\hline 29 & Heri H & $57.00 \times 30$ & $57.50 \times 10$ & $62.50 \times 15$ & $53.75 \times 45$ & 56.41 & Optimal Load \\
\hline 30 & Aep Cahyana & $70.50 \times 15$ & $63.50 \times 35$ & $62.50 \times 20$ & $70.50 \times 30$ & 66.45 & Over Load \\
\hline 31 & Usep Rodita & $63.50 \times 10$ & $73.00 \times 45$ & $55.50 \times 30$ & $75.00 \times 15$ & 67.10 & Over Load \\
\hline 32 & Trisnos & $35.00 \times 10$ & $48.33 \times 30$ & $38.50 \times 20$ & $46.50 \times 40$ & 44.30 & Optimal Load \\
\hline 33 & Dandung $P$ & $60.00 \times 15$ & $69.00 \times 40$ & $68.00 \times 30$ & $71.00 \times 15$ & 67.65 & Over Load \\
\hline 34 & Asep Jaenudin & $64.00 \times 25$ & $71.50 \times 25$ & $62.50 \times 25$ & $73.50 \times 25$ & 67.88 & Over Load \\
\hline & Rata-Rata & 11.53 & 21.38 & 15.51 & 13.72 & 62.14 & Over Load \\
\hline
\end{tabular}

Tabel 14. Hasil rekapitulasi skor beban kerja dengan menggunakan metode DRAWS untuk supervisor

\begin{tabular}{|c|c|c|c|c|c|c|c|}
\hline \multirow{2}{*}{ No } & \multirow{2}{*}{ NAMA } & \multicolumn{4}{|c|}{ Skoring } & \multirow{2}{*}{ Total (\%) } & \multirow{2}{*}{$\begin{array}{c}\text { Kategori Bebar } \\
\text { Kerja }\end{array}$} \\
\hline & & Input Demand & Central Demand & Output Demand & Time Pressure & & \\
\hline 1 & R. Usman & $63.33 \times 30$ & $70.00 \times 30$ & $73.33 \times 20$ & $70.00 \times 20$ & 68.67 & Over Load \\
\hline 2 & Dian Suyud & $71.67 \times 10$ & $67.25 \times 40$ & $66.33 \times 30$ & $73.00 \times 20$ & 68.57 & Over Load \\
\hline 3 & Yayan Sugiharjo & $59.33 \times 23$ & $57.00 \times 27$ & $57.00 \times 26$ & $60.00 \times 24$ & 58.26 & Optimal Load \\
\hline 4 & Dedi Ruswendi & $61.00 \times 13$ & $52.50 \times 42$ & $65.00 \times 28$ & $71.50 \times 17$ & 60.34 & Over Load \\
\hline 5 & Kohar Fahrudin & $59.33 \times 30$ & $43.75 \times 20$ & $60.50 \times 25$ & $57.50 \times 25$ & 56.05 & Optimal Load \\
\hline 6 & Budi Rahmat S.A.S & $83.33 \times 20$ & $83.75 \times 35$ & $75.00 \times 20$ & $87.50 \times 25$ & 82.85 & Over Load \\
\hline 7 & Suhardi & $65.00 \times 30$ & $73.75 \times 40$ & $65.00 \times 15$ & $60.00 \times 15$ & 67.75 & Over Load \\
\hline 8 & Agung WahyuS & $53.67 \times 37$ & $56.25 \times 30$ & $42.50 \times 16$ & $61.00 \times 17$ & 53.90 & Optimal Load \\
\hline 9 & Fajar Fatahillah & $80.00 \times 10$ & $90.00 \times 60$ & $92.50 \times 15$ & $80.00 \times 15$ & 87.88 & Over Load \\
\hline 10 & Yunar Wahyudi & $66.67 \times 20$ & $75.00 \times 35$ & $67.50 \times 20$ & $75.00 \times 25$ & 71.83 & Over Load \\
\hline 11 & Dadan Mardiana & $69.67 \times 30$ & $67.50 \times 30$ & $67.50 \times 20$ & $67.50 \times 20$ & 68.15 & Over Load \\
\hline 12 & Ima Wardani & $70.00 \times 20$ & $50.00 \times 40$ & $80.00 \times 25$ & $67.50 \times 15$ & 64.13 & Over Load \\
\hline 13 & Tito Gitaraharja & $66.67 \times 10$ & $41.25 \times 50$ & $70.00 \times 20$ & $70.00 \times 20$ & 55.29 & Optimal Load \\
\hline 14 & Satrio & $71.67 \times 40$ & $51.25 \times 20$ & $65.00 \times 20$ & $72.50 \times 20$ & 66.42 & Over Load \\
\hline 15 & Lies Purwaty & $66.67 \times 30$ & $50.00 \times 30$ & $75.00 \times 20$ & $70.00 \times 20$ & 64.00 & Over Load \\
\hline 16 & Avep Sanusi & $71.67 \times 35$ & $56.25 \times 35$ & $75.00 \times 10$ & $70.00 \times 20$ & 66.27 & Over Load \\
\hline 17 & Syaefuddin & $76.67 \times 5$ & $66.00 \times 15$ & $82.00 \times 40$ & $81.67 \times 40$ & 79.20 & Over Load \\
\hline & Rata-Rata & 15.41 & 21.51 & 15.14 & 14.96 & 67.03 & Over Load \\
\hline
\end{tabular}

Berdasarkan hasil perhitungan beban kerja terhadap Managerial Level di Departemen UHT, kemudian selanjutnya dihitung rata-rata dari setiap variabel beban kerja fisik dan mental sebagaimana disajikan pada tabel 15 .

Tabel 15. Kategori beban kerja untuk managerial level

\begin{tabular}{|c|c|c|c|c|c|}
\hline \multicolumn{6}{|c|}{ Kategori Beban Kerja } \\
\hline \multirow[b]{2}{*}{ Jabatan } & \multicolumn{2}{|c|}{ Beban Kerja Fisik } & \multicolumn{2}{|c|}{ Beban Kerja Mental } & \multirow[b]{2}{*}{ Jumlah $(\%)$} \\
\hline & $\begin{array}{l}\text { Rata-Rata } \\
\text { Input Demand } \\
\text { (ID) }\end{array}$ & $\begin{array}{c}\text { Rata-Rata } \\
\text { Output Demand } \\
\text { (OD) }\end{array}$ & $\begin{array}{l}\text { Rata-Rata } \\
\text { Central Demand } \\
\text { (CD) }\end{array}$ & $\begin{array}{c}\text { Rata-Rata } \\
\text { Time Pressure } \\
\text { (TP) }\end{array}$ & \\
\hline Managerial Level & 9.40 & 19.00 & 41.40 & 30.20 & 100.00 \\
\hline Rata-Rata Beban Kerja & \multicolumn{2}{|c|}{28.40} & \multicolumn{2}{|c|}{71,60} & 100 \\
\hline
\end{tabular}

Berdasarkan tabel 15, menunjukkan bahwa beban kerja yang paling dominan dirasakan Managerial Level adalah variabel Central Demand sebesar $41,40 \%$ dengan sebaran beban kerja fisik sebesar $28,40 \%$ dan beban kerja mental sebesar $71,60 \%$. Jadi beban kerja yang dirasakan lebih banyak oleh Managerial Level dalam melakukan pekerjaanya termasuk kedalam beban kerja mental dengan rata-rata beban kerja sebesar $71,60 \%$. Artinya jenis pekerjaan yang dilakukan oleh Managerial Level di Departemen UHT didominasi oleh pekerjaan mental. Seorang manajer sebagai garda terakhir pengambil keputusan di suatu perusahaan, meskipun memungkinkan terjadinya human error dalam pengambilan keputusan tersebut maka untuk seorang manajer tidak boleh terjadi sama sekali. Seorang manajer harus berani mengambil resiko dalam mengambil keputusan (Griffin, $2013: 259)$

Tabel 16. Kategori beban kerja untuk supervisory level

\begin{tabular}{|c|c|c|c|c|c|}
\hline \multicolumn{6}{|c|}{ Kategori Beban Kerja } \\
\hline \multirow{4}{*}{ Jabatan } & \multicolumn{2}{|c|}{ Beban Kerja Fisik } & \multicolumn{2}{|c|}{ Beban Kerja Mental } & \multirow{4}{*}{ Jumlah (\%) } \\
\hline & Rata-Rata & Rata-Rata & Rata-Rata & Rata-Rata & \\
\hline & Input Demand & Output Demand & Central Demand & Time Pressure & \\
\hline & (ID) & (OD) & (CD) & (TP) & \\
\hline Assistant Supervisor & 19.79 & 25.12 & 33.21 & 21.88 & . \\
\hline Supervisor & 23.12 & 21.76 & 34.06 & 21.06 & . \\
\hline Rata-Rata & 21.46 & 23.44 & 33.63 & 21.47 & 100 \\
\hline Rata-Rata Beban Kerja & \multicolumn{2}{|c|}{44.90} & \multicolumn{2}{|c|}{55.10} & 100 \\
\hline
\end{tabular}

Berdasarkan tabel 16, menunjukkan bahwa beban kerja yang paling dominan dirasakan Supervisory Level adalah variabel Central Demand sebesar $33,63 \%$ dengan sebaran beban kerja fisik sebesar $44,90 \%$ dan beban kerja mental sebesar $55,10 \%$. Jadi beban kerja 
mental yang dirasakan oleh Supervisory Level masih relatif sebanding dibandingkan beban kerja fisiknya, dan berbeda yang dirasakan oleh Managerial Level dimana lebih didominasi oleh beban kerja mental. Dengan demikian, Supervisory Level harus meningkatkan ketrampilan dan pengetahuan dalam ruang lingkup kerjanya, sehingga dapat memberikan kontribusi yang lebih baik terhadap perusahaan (Gilley \& Maycunich, $2000: 241$ ).

\section{Implementasi Hasil Penelitian}

Sebagai upaya untuk meningkatkan produktivitas pegawai, maka hasil pengukuran beban kerja pegawai yang telah dilakukan oleh perusahaan dapat dijadikan acuan dalam penetapan standar beban kerja maksimum. Untuk Managerial Level, yang terdiri dari 2 orang manajer dan 3 orang shift manager, dimana keseluruhannya berada dalam kategori beban kerja yang tinggi (overload) dan skor tertinggi beban kerja adalah sebesar $72,32 \%$. Skor ini sebagai skor standar beban kerja untuk Managerial Level di Departemen UHT PT. Ultrajaya. Sudah sepantasnyalah kalau level manajer berada pada kategori beban kerja overload, tetapi skornya tidak berlebihan (kategori sangat tinggi). Dengan skor beban kerja untuk manajer sebesar $72,32 \%$ adalah sudah cukup baik, karena seorang manajer harus dapat mengendalikan tingkat stress pekerjaan dan mengendalikan konflik yang terjadi di perusahaan, sehingga sedemikian rupa perkembangan organisasi bisa diciptakan dengan baik dan dapat mewujudkan apa yang menjadi visi dan misi dalam organisasinya (Reis \& Geller, $2010: 6$ ).

Untuk Supervisory Level dimana rata-rata skor beban kerja berada dalam kategori overload, yakni sebanyak 37 orang dari 51 pegawai yang overload, dan 6 orang yang skornya melebihi skor manajer. Dengan demikian, kita dapat menetapkan skor standar beban kerja maksimal adalah sebesar $72,32 \%$, dimana untuk pegawai yang skornya di atas nilai standar maksimum ini, maka pegawai tersebut dilakukan pembinaan dan pelatihan sehingga sedemikian rupa pada satu tahun ke depan dapat memenuhi nilai standar beban kerja tersebut.

Dengan ditetapkannya nilai standar beban kerja maksimum, maka para pegawai diharapkan dapat meningkatkan kedisplinan dan kemampuan \& keterampilan kerja sehingga dapat meningkatkan produktivitas perusahaan. Skor ini juga dapat diaplikasikan dalam perekutan pegawai untuk managerial \& supervisory level di departemen UHT PT. Ultrajaya.

\section{Simpulan}

Berdasarkan hasil pengolahan dan pembahasan hasil penelitian di lapangan, maka dapat ditarik kesimpulan:

1. Besarnya beban kerja yang dirasakan oleh Managerial Level dan Supervisory Level melalui proses pengukuran beban kerja DRAWS adalah sebagai berikut:

a) Managerial Level di Departemen UHT PT. Ultrajaya menilai bahwa beban kerja yang dirasakan adalah over load dengan rata-rata skor beban kerja sebesar $67,36 \%$, dimana kompetensi seorang manager pasti memiliki beban kerja yang sangat tinggi dan dituntut untuk memiliki daya fikir yang kreatif, dinamis dan visioner yang dapat membawa kesinambungan perusahaan ke arah yang lebih baik.

b) Supervisory Level di Departemen UHT PT. Ultrajaya menilai bahwa beban kerja yang dirasakan adalah termasuk overload dengan rata-rata skor beban kerja sebesar $64,59 \%$, dimana Supervisory Level dituntut untuk meningkatkan ketrampilan dan pengetahuan dalam ruang lingkup kerjanya, sehingga dapat memberikan kontribusi yang lebih baik terhadap perusahaan dan memberikan informasi yang benar terhadap manager perusahaan sebagai bahan pengambilan keputusan.

2. Variabel beban kerja DRAWS yang paling dominan dirasakan oleh Managerial Level dan Supervisory Level adalah sebagai berikut:

a) Managerial Level dari keempat variabel beban kerja DRAWS adalah variabel Central Demand (CD) sebesar $41.40 \%$ dengan sebaran beban kerja beban kerja mental sebesar $71,60 \%$ dan beban kerja fisik sebesar $28,40 \%$, dimana Mangerial Level Management dalam bekerja lebih banyak aktivitas berpikir menggunakan otaknya, dibandingkan tenaga fisik yang dikeluarkan.

b) Supervisory Level dari keempat variabel beban kerja DRAWS adalah variabel Central Demand (CD) sebesar 33,63\% dengan sebaran beban kerja fisik sebesar $44,90 \%$ dan beban kerja mental sebesar $55,10 \%$, dimana relatif terdapat keseimbangan beban kerja mental dan beban kerja fisik, sehingga diperlukan 
tenaga fisik yang sebanding dalam menunjang pekerjaanya.

\section{Daftar Pustaka}

Gilley, Jerry, and Maycunich, Ann. (2000). Beyond The Organization Enhancing Your Company's Capability. New York : Perseus Books.

Griffin, W. Ricky. (2012). Management $\left(11^{\text {st }}\right.$ Ed.). USA : Cengage Learning.

Institute for Occupational Ergonomics (IOE). (2005). Train Driver Mental Workload: The Train Driver DRAWS Tool Guidance Note. Research Programme. Rail Safety \& Standard Board. Diakses dari : http://p.sparkrail.org/record.asp?q=PB0094 02. [20 Februari 2015].

Reis, Matthew, and Geller, Judith. (2010). A manager's Guide to Human Behavior. USA : American Management Association.

Salmon, Paul, Stanton, Neville, Baber,Chris, Walker, Guy, and Green, Damian. (2004). Human Factors Design \& Evaluation Methods Review. Human Factors Integration Defence Technology Centre. Diakses dari :

https://www.defencehumancapability.com/P ortals/0/HFIDTC/HFI\%20Methods\%20and\% 20Models/Phase $\% 201 /$ hf-design-

evaluation-methods.pdf. [20 Februari 2015].

Stanton, Neville, Salmon, Paul M., and Rafferty, Laura A. (2005). Human Factors Methods: A Practical Guide for Engineering and Design. England: Ashgate Publishing Company.

Ultrajaya Milk Industry \& Trading Co. TBk, PT. Ultrajaya at Glance, Bandung, [On Line], Diakses dari:

http://www.ultrajaya.co.id/corporatehall/ultra jayaataglance/. [20 Februari 2015].

Ultrajaya Milk Industry \& Trading Co. TBk. (2015). Usaha \& Kinerja Terkini untuk 9 Bulan 2015. Bandung : PT. UJMI.

\section{Lampiran}

Deskripsi Dimensi DRAWS Manager Produksi

\begin{tabular}{|c|c|c|}
\hline Jabatan & Variabel & Aktivitas \\
\hline \multirow{4}{*}{ Manager Produksi } & Input Demand & $\begin{array}{l}\text { Membaca laporan Planning Produksi. } \\
\text { Membaca laporan harian Process, Sterilizer, Filling, Packing, Robotic, General admin. } \\
\text { Membaca target produks Process, Filling dan Finish Goods. }\end{array}$ \\
\hline & Central Demand & $\begin{array}{l}\text { Mengarahkan Assistant Manager, Supervisor, Assistant Supervisor. } \\
\text { Menghitung kapasitas mesin dan manpower yang bekerja. } \\
\text { Mengidentifikasi kerusakan pada Raw Material, Mesin, WIP dan Finish Goods. } \\
\text { Membuat keputusann Kualitas mesin, WIP dan Finish Goods. }\end{array}$ \\
\hline & Output Demand & $\begin{array}{l}\text { Rekomendasi Ke PPIC untuk Planning Produksi. } \\
\text { Rekomendasi ke Maintenance dan Utility untuk perbaikan mesin. } \\
\text { Rekomendasi ke QC untuk Kualitas WIP dan Finish Goods. } \\
\text { Rekomendasi ke WVP untuk Sugar Syrup. } \\
\text { Rekomendasi ke Warehouse untuk Hasil Produksi Finish Goods. }\end{array}$ \\
\hline & Time Pressure & $\begin{array}{l}\text { Menyelesaikan Produks i sesuai target waktu. } \\
\text { Menyelesaikan Planning Prdouksi harian Sesuai target waktu. } \\
\text { Menyelesaiakn Performance Appraisal Supervisor, Assistant Supervisor dan Staff tepat wakktu. } \\
\text { Menyelesaikan Improvement Project dengan baik dan tepat waktu. }\end{array}$ \\
\hline
\end{tabular}

Deskripsi Dimensi DRAWS Supervisor Process

\begin{tabular}{|c|c|l|}
\hline Jabatan & \multicolumn{1}{|c|}{ Variabel } & \multicolumn{1}{|c|}{ Aktivitas } \\
\hline \multirow{5}{*}{ Supervisor Process } & Input Demand & $\begin{array}{l}\text { Membaca laporan Planning Produksi. } \\
\text { Membaca laporan harian Process. } \\
\text { Membaca target produksi Mixing. }\end{array}$ \\
\cline { 2 - 3 } & \multirow{2}{*}{ Central Demand } & $\begin{array}{l}\text { Mengatur mesin dan operator yang bekerja. } \\
\text { Menghitung jumlah recipe dan raw material untuk tiap Mixing. } \\
\text { Mengidentifikasi kerusakan pada mesin dan recipe. } \\
\text { Membuat keputusan kualitas recipe yang dimixing. }\end{array}$ \\
\cline { 2 - 3 } & $\begin{array}{l}\text { Rekomendasi ke Warehouse untuk Raw Material. } \\
\text { Rekomendasi ke Sterilizer untuk transfer WIP Produk. } \\
\text { Rekomendasi ke MVP untuk Sugar Syrup. }\end{array}$ \\
\cline { 2 - 3 } & Time Pressure & $\begin{array}{l}\text { Menyelesaikan Mixing sesuai target waktu. } \\
\text { Menyelesaikan laporan dengan baik dan tepat waktu. }\end{array}$ \\
\hline
\end{tabular}

